\title{
Memperkuat Hubungan Antar Lembaga Negara Dalam Bingkai Negara Hukum*
}

\author{
(Strengthening of Coordination Between State Institutions \\ As Rechstaat Framework) \\ Indra Rahmatullah, Rizza Zia Agusty \\ Universitas Islam Negeri Syarif Hidayatullah Jakarta \\ Jl. H. Juanda No. 95 Ciputat Tangsel \\ E-mail: indra.r86@gmail.com, rizza@gmail.com
}

doi $\underline{10.15408 / \text { sjsbs.v3i2.7856 }}$

\begin{abstract}
:
The authority of the state is not powered by one person or one institution only, but also it should be a separation of power. The separation pf power from trias politica theory is difficult to be implemented because no other state body that untouchable. That is why the theory of distribution power developed become the check and balances theory. The development of check and balances theory is signed by the amandement UUD 1945. The goal of check and balances system is to maximize the function state body and to limit abuse of power. In fact, there is always conflict between state bodies because of their power and duty.
\end{abstract}

Keywords: Check and balances, state body, and conflict.

\begin{abstract}
Abstrak:
Kekuasaan negara tidak terpusat pada satu orang atau lembaga saja, tetapi perlu adanya pemisahan kekuasaan (separation of power). Separation of power dari trias politica sebelumnya sulit terlaksana karena satu sama lain lembaga negara tidak mungkin tidak saling bersentuhan, sehingga berkembanglah menjadi teori pembagian kekuasaan (distribution of power) dan berujung dengan lahirnya teori checks and balances. Perkembangan ketatanegaraan di Indonesia yang mengarah pada sistem checks and balances ditandai dengan adanya amandeman UUD 1945 yakni lembaga negara yang saling mengawasi dan mengimbangi lembaga negara lainnya. Tujuan checks and balances adalah memaksimalkan fungsi masing-masing lembaga negara dan membatasi kesewenang-wenangan lembaga negara. Pada kenyataanya, mulai ada ketegangan dan konflik antar lembaga negara yang diakibatkan lembaga negara tersebut merasa memiliki kekuatan yang sama.
\end{abstract}

Kata kunci: Checks and balances, lembaga negara, dan konflik.

${ }^{*}$ Diterima tanggal naskah diterima: 12 Maret 2016, direvisi: 22 April 2016, disetujui untuk terbit: 20 Mei 2016. 


\section{Pendahuluan}

Menurut perkembangan sejarah ketatanegaraan kata pemisahan kekuasaan, pertama kali dicetuskan oleh John Locke yang membagi kekuasaan negara dalam tiga fungsi, tetapi berbeda isinya. Menurutnya, fungsi-fungsi kekuasaan negara meliputi: fungsi legislatif, fungsi eksekutif, dan fungsi federatif. Selanjutnya, konsep pemisahan kekuasaan yang dikemukakan John Locke dikembangkan lebih lanjut setengah abad kemudian dalam abad ke XVIII oleh Charles Secondat Baron de Labrede et de Montesquieu (1668-1748) dalam karyanya L'Espirit des Lois (The Spirit of the Laws). ${ }^{1}$

Montesquieu membagi kekuasaan pemerintahan dalam tiga cabang, yaitu kekuasaan membuat undang-undang (legislatif), kekuasaan untuk menyelenggarakan undang-undang yang oleh Montesquieu diutamakan tindakan di bidang politik luar negeri (eksekutif) dan kekuasaan mengadili terhadap pelanggaran undang-undang (yudikatif). Tegasnya Montesquieu mengatakan, kekuasaan itu harus terpisah satu sama lain, baik mengenai tugas (fungsi) maupun mengenai alat perlengkapan (lembaga) yang menyelenggarakannya. Konsepsi ini lebih dikenal dengan ajaran Trias Politica. Separation of power dari trias politica sebelumnya sulit terlaksana karena satu sama lain lembaga negara tidak mungkin tidak saling bersentuhan, sehingga menyebabkan teori pembagian kekuasaan (distribution of power) lebih berkembang, digunakan di berbagai Negara, dan berujung dengan lahirnya teori checks and balances.

Perkembangan ketatanegaraan di Indonesia yang mengarah pada sistem checks and balances ditandai dengan adanya amandeman UUDNRI 1945 yakni lembaga negara yang saling mengawasi dan mengimbangi lembaga negara lainnya. Indonesia membagi kekuasaan pemerintahan kepada eksekutif yang dilaksanakan oleh presiden, legislatif oleh Dewan Perwakilan Rakyat (DPR), dan yudikatif oleh Mahkamah Agung, Mahkamah Konstitusi dan Komisi Yudisial.

Sejarah ketatanegaran Indonesia di masa Orde Baru hampir tidak mengenal adanya checks and balances di antara lembaga negara karena realitas kekuasaan terpusat pada Presiden.2 Perubahan UUD 1945 melahirkan satu kekuatan penyeimbang yang dibangun secara fungsional dalam bentuk

1 Diunduh dari http://www.jimlyschool.com/read/analisis/333/checks-and-balances-danjudicial-review-dalam-legislasi-di-indonesia/ pada tanggal 27 Oktober 2015, dapat ditelusuri pada Carl Schmitt,Constitutional Theory, Translated and edited by Jeffrey Seitzer, Duke University Press, Durham and London, 2008, h. 230.

2 Diunduh dari http://www.jimlyschool.com/read/analisis/333/checks-and-balances-danjudicial-review-dalam-legislasi-di-indonesia/ pada tanggal 27 Oktober 2015, dapat ditelusuri pada Sekretariat Jenderal MPRR.I., Panduan Dalam Memasyarakatkan UndangUndang DasarNegara Republik Indonesia Tahun 1945, Latar Belakang, Proses dan Hasil Perubahan Undang-Undang Dasar Negara Republik Indonesia Tahun 1945 (Jakarta: Sekretariat Jenderal MPR R.I. 2003) h. 14. 
kelembagaan yang setara. Jika dihadapkan dengan doktrin klasik separation of powers, kekuasaan negara yang diberikan kepada lembaga-lembaga yang terpisah satu dengan lainnya dalam rangka menghindarkan terjadinya campur tangan yang satu terhadap yang lain, maka mekanisme checks and balances pasca perubahan UUD 1945 tampaknya dapat juga dianggap satu pelunakan terhadap doktrin separation of powers atau pembagian kekuasaan negara dengan menghubungkan cabang kekuasaan yang saling terpisah. Hal ini dimaksudkan untuk mencegah lahirnya kekuasaan yang bersifat mutlak tanpa pengawasan.

Pada check and balance antar-tiga unsur trias politica yang terpisah, yakni legislatif, eksekutif, dan yudikatif, ini pun harus didukung dengan penegakan hukum dan kontrol masyarakat sipil. Pada demokrasi tua seperti Australia, trias politica tak selalu terpisah nyata. Tapi check and balance terpelihara, utamanya berkat tradisi oposisi yang jelas dan melembaga. Pada demokrasi seperti Indonesia, tantangannya justru disfungsi trias politica, sehingga check and balance tak tercipta. ${ }^{3}$ Ditambah lagi dengan mentalitas para penjabat yang ada dalam ketiga lembaga tersebut (eksekutif, legislatif dan yudikatif), yang apabila di antara mereka sedang melakukan fungsi checks and balances, pihak yang diperiksa merasa diganggu independensinya.

Pada kenyataanya, mulai ada ketegangan dan kekacauan hubungan antar lembaga negara yang diakibatkan lembaga negara tersebut merasa memiliki kekuatan yang sama. Sebagai contoh ialah beberapa polemik pertama kasus UU Pilkada antara DPR dan Presiden. Pada tanggal 26 September 2014, DPR mengesahkan Undang-Undang Pilkada yang baru. Dalam putusan yang diambil melalui voting atau pemunggutan suara, fraksi pendukung Pilkada lewat DPRD, yakni fraksi PAN, PPP, Gerindra, PKS dan Golkar unggul dengan 256 suara. Fraksi lain pendukung Pilkada Lansung kalah dengan 135 suara. Presiden Susilo Bambang Yudoyono (SBY), menerbitkan Perppu untuk membatalkan UU Pilkada yang baru dan mempertahankan Pilkada Langsung dengan perbaikan. ${ }^{4}$

Kasus kedua DPR melawan Presiden yang melibatkan unsur dari Polri dengan KPK, yang diberi julukan oleh masyarakat yaitu cicak melawan buaya. Kasus terakhir ini seputar pencalonan Budi Gunawan sebagai Kapolri dan kasus kriminalisasi Abraham Samad dan Bambang Widjajanto. Pada berita Nasional Kompas, Jimly mengatakan, "saat ini KPK tidak bisa melanjutkan kasus Budi Gunawan karena kasasinya ditolak. Sementara KPK juga tak bisa mengajukan peninjauan kembali. Sehingga untuk sementara waktu, kasus Budi Gunawan berhenti. Dalam kondisi seperti ini, Polri, kata Jimly, harusnya melepaskan Bambang dan Abraham dari jerat ancaman pidana. Pasalnya, penetapan dua

\footnotetext{
${ }^{3}$ Gatra News, Selasa/ 2 April 2013, "Korupsi dan Trias Politica", oleh Abdul Aziz.

4 Tempo, Selasa/30 September 2014, "SBY Siapkan Perpu Batalkan UU Pilkada", oleh Prihandoko.
} 
pimpinan KPK non-aktif sebagai tersangka tidak terlepas dari penetapan tersangka yang dilakukan KPK terhadap Budi Gunawan." ${ }^{5}$

Selanjutnya kasus ketiga antara Mahkamah Agung (MA), Mahkamah Konstitusi (MK) dan Komisi Yudisial (KY). Antara ketiga lembaga ini selalu terdapat selisih pendapat, dimulai dari Ikatan Hakim Indonesia (IKAHI) yang mengajukan judicial review ke MK tentang keikutsertaan KY dalam rekruitmen calon hakim. Selain itu ditambah dengan kasus "MA memutuskan menolak rekomendasi KY terkait dugaan pelanggaran kode etik hakim Sarpin Rizaldy."6 Di sisi lain hakim MK tak mau diawasi KY. Dengan suara bulat, kesembilan hakim konstitusi berpendapat bahwa mereka tidak termasuk objek pemeriksaan Komisi Yudisial.7 Gesekan-gesekan ini seharusnya tidak terjadi jika prinsip checks and balances dimaknai dan dilaksanakan dengan benar. Ketegangan antar lembaga negara tersebut tidak pelak ujungnya akan merugikan masyarakat.

\section{Pembagian Kekuasaan dan Ajaran Checks and Balances}

Mengenai teori pembagian kekuasaan negara sebagaimana kita ketahui, teori yang paling terkenal adalah trias politika milik Montesquiue. Namun seiring perkembangan dunia akademik teori tersebut semakin berkembang, sebagaimana teori yang disampaikan Van vollen hoven menjelaskan mengenai pembagian negara menjadi 4, yakni: bestuur (ketataprajaan/pemerintah), regeling (pengawasan), politie (pengaturan), dan rechtspraak/justitie (penyelesaian sengketa). ${ }^{8}$ Sedangkan Lamaire membagi tugas negara dalam jenis yaitu: perundang-undangan, pelaksanaan yaitu pembuatan aturan-aturan hukum oleh penguasa sendiri, pemerintahan, kepolisian, dan pengadilan. ${ }^{9}$

Sebagaimana telah diamanahkan oleh Konstitusi Indonesia yakni UUDNRI 1945 bahwa dalam hal menjalankan fungsi kenegaraan dengan menggunakan ajaran pembagian kekuasaan (machtsverdeling atau distribution of power), yang menekankan pentingnya pembagian fungsi bukan pembagian lembaga, dan ajaran checks and balances yang menekankan pentingnya hubungan saling mengawasi dan mengendalikan antarberbagai lembaga negara, esensi bahwa kekuasaan negara itu harus dibagi atau dipisah masih tetap relevan. ${ }^{10}$

5 Kompas, 1 Maret 2015 diunduh pada tanggal 27 Oktober 2015 dari situs http://nasional.kompas.com/read/2015/03/01/19475521/Jimly.Kasus.Budi.Gunawan.Berhenti.Abraha m.Samad.dan.Bambang.Widjojanto.Juga.Harus.Dihentikan.

${ }^{6}$ Antara News, Rabu/ 19 Agustus 2015 diunduh pada tanggal 27 Oktober 2015 dari situs http://www.antaranews.com/berita/513237/ma-tolak-rekomendasi-ky-soal-hakim-sarpin.

${ }^{7}$ Hukum Online, Kamis/24 Agustus 2006, diunduh pada tanggal 27 Oktober 2015, pada situs http://www.hukumonline.com/berita/baca/hol15347/hakim-mk-tak-mau-diawasi-ky.

${ }^{8}$ Ridwan, HR. Hukum Administrasi Negara. (Jakarta: RajaGrafindo Persada, 2007). h. 14

${ }^{9}$ Ridwan, HR. Hukum Administrasi Negara. (Jakarta: RajaGrafindo Persada, 2007). h. 14.

${ }^{10}$ Ridwan, HR. Hukum Administrasi Negara. (Jakarta: RajaGrafindo Persada, 2007), h.13 
Menurut Black Law Dictionary, checks and balances is arrangement of governmental power whereby powers of one governmental branch check or balance those of other branches. See also separation of power. ${ }^{11}$ Tujuan checks and balances adalah memaksimalkan fungsi masing-masing lembaga negara dan membatasi kesewenang-wenangan lembaga negara.

Dalam hal menata kekuasaan lain di luar tiga kekuasaan menurut Montesquieu, Crince le Roy menyimpulkan membangun sistem checks and balances. Menurut Crince le Roy negara merupakan lembaga penertib. ${ }^{12}$ Negara merupakan organisasi kekuasaan dengan obyek kegiatan penertiban terhadap suatu masyarakat tertentu secara menyeluruh dengan mempergunakan kekuasaannya. ${ }^{13}$ Bertitik tolak dari kegiatan penertiban tersebut, disusunlah fungsi negara yang dilaksanakan oleh badan-badan negara yang bebas dan terpisah satu dengan yang lainnya yang ditambah suatu sistem pengawasan untuk menghindarkan salah satu alat kekuasaan akan menarik seluruh kekuasaan ke dalam dirinya yang disebut dengan sistem checks and balances.

Checks and balances ini, yang mengakibatkan satu cabang kekuasaan dalam batas-batas tertentu dapat turut campur dalam tindakan cabang kekuasaan lain, tidak dimaksud untuk memperbesar efisiensi kerja (seperti yang dilihat di Inggris dalam fungsi dari kekuasaan eksekutif dan legislatif), tetapi untuk membatasi kekuasaan dari setiap cabang kekuasaan secara efektif.

Hal ini berarti sistem checks and balances dalam penyelenggaraan kekuasaan memungkinkan adanya saling kontrol antar cabang kekuasaan yang ada dan menghindari tindakan-tindakan hegemonik, tiranik dan sentralisasi kekuasaan. ${ }^{14}$ Sistem ini mencegah terjadinya overlapping antar kewenangan yang ada. ${ }^{15}$ Begitu pula dengan pendapat Jimly Asshiddiqie adanya sistem checks and balances mengakibatkan kekuasaan negara dapat diatur, dibatasi bahkan dikontrol dengan sebaik-baiknya, sehingga penyalahgunaan kekuasaan oleh aparat penyelenggaraan negara yang menduduki jabatan dalam lembaga negara dapat dicegah dan ditanggulangi dengan sebaik-baiknya. ${ }^{16}$

Bukti sistem di Indonesia melaksanakan ajaran sistem checks and balances adalah Presiden sebagai pemegang kekuasaan eksekutif (yang seharusnya

${ }^{11}$ Black Law Dictionarry By Henry Campbel, (St. Paul: West Publishing Co., 1990), h. 238.

12 Crince le Roy, Kekuasaan ke-empat Pengenalan Ulang, diterjemahkan oleh Soehardjo, (Semarang: 1981), h. 42.

${ }_{13}$ Crince le Roy, Kekuasaan ke-empat Pengenalan Ulang, diterjemahkan oleh Soehardjo, (Semarang: 1981), h. 42.

14 A. Fickar Hadjar ed. al, Pokok-pokok Pikiran dan Rancangan Undang-Undang Mahkamah Konstitusi, (Jakarta: KRHN dan Kemitraan, 2003), h. 4.

15 A. Fickar Hadjar ed. al, Pokok-pokok Pikiran dan Rancangan Undang-Undang Mahkamah Konstitusi, (Jakarta: KRHN dan Kemitraan, 2003), h. 4.

16 Jimly Asshiddiqie, Konstitusi dan Konstitusionalisme Indonesia, (Jakarta: Sekretariat Jenderal dan Kepaniteraan Mahkamah Konstitusi RI, 2006). h. 74. 
memiliki fungsi untuk melaksanakan undang-undang) namun UUDNRI 1945 memberikan hak kepada presiden untuk melaksanakan fungsi legislasi semu yakni dapat mengajukan rancangan undang-undang kepada DPR, pemerintah (eksekutif) juga memiliki kewenangan untuk justitie (penyelesaian sengketa), dan pengawasan (control).

DPR juga sebagai lembaga negara yang memiliki fungsi legislasi (membuat undang-undang), namun konstitusi juga melengkapi DPR dengan fungsi anggaran dan pengawasan: ${ }^{17}$

a. Membahas dan memberikan persetujuan atau tidak memberikan persetujuan terhadap rancangan undang-undang tentang APBN yang diajukan oleh Presiden.

b. Pengawasan atas pelaksanaan undang-undang dan APBN.

Untuk mempertajam analisis Penulis, argumentasi Saldi Isra sangat relevan untuk memperkuat standing Penulis. Saldi Isra memberikan analisis yang tajam terkait dengan khittah prinsip checks and balances. Menurut Saldi Isra, sejak selesainya Perubahan UUD 1945 Generasi Pertama (1999-2002), pembedaan lembaga-lembaga negara tidak lagi didasarkan kepada pembagian hierarkis berupa lembaga tertinggi negara dan lembaga tinggi negara. Setelah perubahan, lembaga-lembaga negara dibedakan sesuai dengan fungsi dan kewenangan konstitusional masing-masing.

Namun, MK melalui Putusan No. 005/PUU-IV/2006 kembali "menghidupkan" pola hubungan antarlembaga negara yang hierarkis. Misalnya, dalam halaman 178-179 Putusan MK No 005/PUU-IV/2006 secara eksplisit dinyatakan:

“...menurut Mahkamah Konstitusi, UUD 1945 dengan jelas membedakan cabangcabang kekuasaan negara dalam bidang legislatif, eksekutif, dan judikatif yang tercermin dalam fungsi-fungsi MPR, DPR dan DPD, Presiden dan Wakil Presiden, serta Mahkamah Agung, Badan Pemeriksa Keuangan, dan Mahkamah Konstitusi sebagai lembaga-lembaga negara yang utama (main state organs, principal state organs). Lembaga-lembaga negara dimaksud itulah yang secara instrumental mencerminkan pelembagaan fungsi-fungsi kekuasaan negara yang utama (main state functions, principal state functions), sehingga oleh karenanya lembaga-lembaga negara itu pula yang dapat disebut sebagai lembaga negara utama (main state organs, principal state organs, atau main state institutions) yang hubungannya satu dengan yang lain diikat oleh prinsip "checks and balances".

Dengan demikian, prinsip checks and balances itu terkait erat dengan prinsip pemisahan kekuasaan negara (separation of powers), dan tidak dapat dikaitkan dengan persoalan pola hubungan antarsemua jenis lembaga negara,

17 Rizza Zia Agusty, dan Suryanto Siyo, “UUDNRI 1945 Lembaga Negara beserta Pimpinannya, peraturan perundang-undangan dan kabinet trisakti. (Jakarta: Visi Media, 2014), h. 50-51. 
seperti misalnya dalam konteks hubungan antara Mahkamah Agung dan Komisi Yudisial. Oleh karena itu, memahami hubungan antara lembaga negara dalam perspektif checks and balances di luar konteks pemisahan fungsi-fungsi kekuasaan negara (separation of powers), seperti dalam hubungan antara Mahkamah Agung dan KY, adalah tidak tepat. Walaupun benar bahwa KY dapat diberi peran pengawasan, maka pengawasan itu bukanlah dalam rangka checks and balances dan juga bukan pengawasan terhadap fungsi kekuasaan peradilan, melainkan hanya pengawasan terhadap perilaku individu-individu hakim.

Dalam pandangan Saldi Isra, Hakim Konstitusi merancukan begitu saja antara separation of power dengan checks and balances. Dalam separation of powers, pembagian secara kaku atas tiga cabang kekuasaan menjadi benar adanya, sedangkan dalam checks and balances pembagian seperti itu bukan menjadi hal yang mutlak. Oleh karenanya, ada pernyataan agak "berbahaya" bagi diskursus ilmu hukum bila interpretasi MK ini dijadikan patokan dalam kontekstualisasi prinsip checks and balances di Indonesia. Dikatakan "berbahaya" karena pertimbangan itu menyempitkan pemahaman cheks and balances pada teks konstitusi, bukan pada prinsip-prinsip.

John A. Garvey dan T. Alexander Aleinikoff menjelaskan bahwa memang ada tiga pendekatan yang digunakan untuk memahami tempat dan hubungan lembaga-lembaga negara, yaitu (1) "separation of powers", (2) "separation of functions", dan (3) "checks and balances". Terkait dengan pendekatan tersebut, Peter L. Strauss (1984) dalam tulisannya "The Place of Agencies in Government: Separation of Powers and Fourth Branch" menjelaskan bahwa:

"unlike the separation of powers, the checks and balances idea does not suppose a radical division of government into three parts, with particular functions neatly parceled out among them. Rather, focus is on relationship and interconnections, on maintaining the conditions in which the intended struggle at the apex may continue."

Berikut ini sejumlah kasus dari terdegradasinya prinsip checks and balances di Indonesia yang menjadi sorotan publik.

\section{Presiden VS DPR Soal Pilkada Langsung/Tidak Langsung}

Rentang Oktober 2014 ramai dibicarakan tentang mekanisme Pilkada apakah langsung atau tidak langsung. Awalnya, melalui RUU Pilkada Gubernur, Bupati dan Walikota mengamini mekanisme Pilkada dengan melalui DPRD dengan berbagai pertimbangan. Atas dasar itu, RUU tersebut kemudian menjadi UU No. 22 Tahun 2014. Namun demikian, banyak desakan dari masyarakat luas agar pemilihan kepala daerah tidak melalui DPRD akan tetapi langsung dipilih oleh rakyat. Mendengar desakan masyarakat luas, akhirnya Presiden SBY kala itu mengeluarkan dua Perppu yaitu Perppu pertama adalah Perppu Nomor 1 Tahun 2014 tentang pemilihan Gubenur/Bupati/Walikota. Perppu ini sekaligus 
mencabut UU No. 22 Tahun 2014 yang mengatakan pemilihan Gubernur/Bupati/Walikota yang mengacu pada pemilihan kepala daerah tak langsung oleh DPRD. Perpppu kedua adalah Perppu Nomor 23 Tahun 2014 tentang pemerintah daerah yang menghapus tugas dan wewenang DPRD memilih kepala daerah.

Banyak orang yang setuju dengan tindakan cepat SBY kala itu untuk meredam gejolak penolakan mekanisme pilkada langsung. Namun, efek sampingnya adalah hubungan yang tidak harmonis antara Presiden dengan DPR. Presiden dianggap mengganjal agenda DPR di mana fraksi-fraksi pada waktu itu telah sepakat dengan cara pilkada melalui DPRD. Bahkan SBY dianggap inkonsistensi karena yang tadinya mendukung pilkada melalui DPRD lantaran didesak oleh publik kembali dengan cara pilkada langsung oleh rakyat. Yang lebih ekstrim, SBY dituding menjadi biang kerok hubungan yang tegang dengan DPR.

Ada juga beberapa orang yang beranggapan bahwa Perppu yang dikeluarkan oleh SBY sejatinya tidak berdasarkan rambu-rambu yang telah ditentukan oleh MK dalam mengeluarkan Perppu. Perppu tersebut ditengarai keluar karena adanya perbedaan arah politik antara Presiden dan DPR bukan karena kebutuhan yag mendesak. Alhasil, dengan mata telanjang kita disodori ruwetnya perbedaan pilkada langsung yang menyita energi dan pikiran kita.

\section{Presiden VS DPR dalam Kasus Pencalonan Budi Gunawan}

Cerita ini dimulai ketika berakhirnya masa jabatan Jendral Sutarman sebagai Kapolri. Berakhirnya Jenderal Sutarman, Presiden mengajukan satu nama sebagai penggantinya yaitu Komjen. Budi Gunawan (BG). Memang di awal-awal munculnya nama Komjen. Budi Gunawan (BG) sudah menimbulkan teka-teki karena nama BG dikaitkan dengan sejumlah perwira di Kepolisian yang memiliki rekening gendut.

Namun demikian, meskipun pencalonan BG diiringi dengan berbagai kontroversi yang mengirinya, DPR tetap memproses usulan nama tersebut untuk segera diadakan Uji Kelayakan (fit and proper test) yang dilakukan oleh Komisi III DPR RI. Pada saat berlangsungnya fit and proper test di DPR, KPK mengumumkan dengan suara yang lantang bahwa Komjen. BG ditetapkan sebagai Tersangka oleh KPK. Komjen BG ditetapkan sebagai tersangka oleh KPK karena diduga terlibat kasus dugaan tindak pidana korupsi penerimaan hadiah atau janji pada saat menduduki jabatan sebagai Kepala Biro Pembinaan Karier Deputi SDM Polri Periode 2003-2006.

Sontak saja kala itu guncangan bagai petir di siang bolong bagi para anggota Komisi III yang sedang melaksanakan fit and proper test. Reaksi pada saat itu tetap dilanjutkan bahkan pada sidang paripurna Komjen BG disahkan 
sebagai Kapolri yang baru menggantikan Jenderal Sutarman. DPR berdalih Presiden tidak dapat semena-mena mengganti Calon Kapolri begitu saja tanpa melalui proses yang ada di DPR. Presiden juga harus menghormati hubungan antar lembaga negara terkait dengan pencalonan BG.

Gelombang protes begitu besar kala itu, akhirnya melalui desakan sanasini Presiden mengirimkan surat resmi kepada DPR untuk mengajukan nama lain yang disodorkan untuk mengganti nama Komjen B. Meskipun telah disahkan oleh DPR, Presiden tidak melantik Komjen BG tetapi mengajukan nama Komjen Badrodin Haiti atas dasar bahwa pencalonan Komjen BG sebagai Kapolri telah menimbulkan perbedaan pendapat di masyarakat dan untuk menciptakan ketenangan dan memperhatikan kebutuhan Kepolisian RI.

Usaha Presiden Jokowi untuk mengganti Komjen BG rupanya mendapat pertentangan yang cukup rumit dari beberapa fraksi di DPR khususnya dari partai pendukungnya. Pasalnya PDIP sebagai partai di mana Presiden Jokowi didukung tetap konsisten untuk segera melantik Komjen. BG walaupun bersebarangan dengan mayoritas masyarakat. Dengan lobby yang alot antar Presiden dan DPR, akhirnya Presiden tidak jadi melantik Komjen BG, namun Presiden mengusulkan Komjen Badrodin Haiti untuk menjadi Calon Kapolri.

Buntutnya, polemik pencalonan BG tersebut rupanya memicu institusi Kepolisian untuk merespon tindakan KPK yang menjadikan Tersangka BG. Akhirnya beberapa Pimpinan KPK seperti Abraham Samad dan Bambang Widjajanto ditetapkan oleh Mabes Polri menjadi tersangka dalam kasus yang berbeda. Drama inilah yang dikenal dan disorot media sebagai bentuk kriminalisasi terhadap KPK oleh Polri. Banyak orang menuding, tindakan Polri merupakan bentuk respon dari status tersangka Komjen BG sebelumnya. Akhirnya Abraham Samad dan Bambang Wdjojanto dinonaktifkan sebagai Pimpinan KPK yang menyebabkan KPK lumpuh.

\section{Kisruh Mahkamah Agung (MA)-Mahkamah Konstitusi (MK)-Komisi Yudisial (KY)}

MA-MK-KY selalu terlibat selisih paham. Ada beberapa contoh yang semakin mentasbihkan hubungan tidak harmonis antar 3 lembaga tersebut diakibatkan komunikasi yang tidak berjalan dengan baik. Pertama, MA dan KY beda pandangan dalam hal kewenangan seleksi hakim tingkat pertama. Beberapa bulan yang lalu, ada kelompok yang mengatasnamakan Ikatan Hakim Indonesia (IKAHI) mengajukan gugatan ke MK. Alasannya cukup sederhana, mereka berkeberatan dan dapat mengganggu independensi MA apabila KY juga ikut campur dalam menyeleksi hakim dari tingkat pertama.

Tak kunjung-kunjungnya selesai konflik antara MA dan KY dalam soal rekrutmen hakim tersebut membuat rekrutmen hakim berhenti. Padahal kalau 
ditelisik lebih jauh, dalam Cetak Biru Pembaharuan Peradilan 2010-2035 yang pernah dikeluarkan oleh MA. MA berkomitmen untuk memperbaiki komunikasi dengan KY dengan mempersiapkan Tim Bersama di dalam melaksanakan proses rekrutmen seperti membentuk tim rekrutmen yang kredibel, membangun konsep dan sistem rekrutmen, membangun profil hakim ideal yang diinginkan, membangun proses, dan membuat sistem monitoring dan evaluasinya. Namun demikian, implementasi dari Cetak Biru itu masih sebatas angan-angan.

Akhirnya berdasarkan Putusan MK No 43/PUU-XIII/2015, KY sudah tidak dilibatkan lagi dalam proses rekrutmen hakim tingkat pertama. Ini berarti MK memenangkan gugatan Ikatan Hakim Indonesia (IKAHI). Namun banyak orang yang mengatakan bahwa putusan MK itu mengandung conflict of interest karena 3 dari 9 hakim di MK adalah anggota IKAHI yaitu Anwar Usman, Suhartoyo, dan Manahan MP Sitompul. Bahkan masyarakat yang mengatasnamakan Forum Kajian Hukum dan Konstitusi (FKHK) akan melaporkan Putusan MK tersebut ke Dewan Etik MK.

Tidak sampai di situ, tentu masih segar dalam ingatan kita konflik MAKY memuncak pada kasus hakim Sarpin. Saat itu MA menolak pemberian sanksi kepada Sarpin atas rekomendasi Komisi Yudisial. Ini semakin jelas ketika secara gamblang ada surat berlabel rahasia ke Sekretariat Jenderal Komisi Yudisial. Isinya, seluruh pimpinan MA sepakat menolak rekomendasi Komisi Yudisial agar hakim Pengadilan Negeri Jakarta Selatan Sarpin Rizaldi diberi sanksi. Buntutnya, penetapan tersangka dua komisioner Komisi Yudisial, Taufiqurrohman Sahuri dan Suparman Marzuki oleh Badan Reserse Kriminal (Bareskrim) Polri dinilai menjadi preseden buruk bagi pengawasan hakim.

Bahkan MK dan KY juga pernah beda persepsi kewenangan perihal siapa yang berhak mengawasi hakim MK. Mahkamah Konstitusi (MK) menolak diawasi Komisi Yudisial (KY). Sebab, 9 hakim konstitusi merasa jabatannya berbeda dengan hakim-hakim biasa. Hal tersebut terungkap dalam salah satu butir putusan MK No 005/PUU-IV/2006. MK juga berpendapat, jika hakim konstitusi menjadi objek pengawasan dari KY, maka akan mengganggu kewenangannya dalam mengawasi konstitusi.

Polemik ini terus berlangsung hingga pada tahun 2013 lalu. Mahkamah Konstitusi menolak diawasi oleh Majelis Kehormatan Hakim Konstitusi permanen, yang semestinya dibentuk bersama oleh Komisi Yudisial dan MK. Penolakan MK ini termaktub dalam putusan yang membatalkan UndangUndang Nomor 4 Tahun 2014 tentang Penetapan Peraturan Pemerintah Pengganti Undang-Undang Nomor 1 Tahun 2013 tentang Perubahan Kedua atas Undang-Undang Nomor 24 Tahun 2003 tentang MK.

Ketika itu MK menolak dengan diterapkannya Majelis Kehormatan Hakim Konstitusi yang di dalamnya terdapat KY dengan dalih prinsip checks and balances itu adalah sebuah mekanisme yang diterapkan untuk mengatur 
hubungan antara kekuasaan legislatif dan eksekutif. Checks and balances tidak ditujukan kepada kekuasaan kehakiman karena antara kekuasaan kehakiman dan cabang kekuasaan yang lain berlaku pemisahan kekuasaan. Prinsip utama yang harus dianut negara hukum adalah kebebasan kekuasaan yudisial atau kehakiman. Karena itu, setiap campur tangan terhadap kekuasaan kehakiman dari lembaga negara apa pun yang menyebabkan tidak bebasnya kekuasaan kehakiman dalam menjalankan fungsinya, akan mengancam prinsip negara hukum.

MK menilai pelibatan KY seperti yang diatur dalam UU Nomor 4 Tahun 2014 merupakan bentuk penyelundupan hukum karena bertentangan dengan Putusan MK Nomor 005/PUU-IV/2006, tertanggal 23 Agustus 2006, yang menegaskan secara konstitusional bahwa Hakim Konstitusi tak terkait dengan KY.

Namun demikian, argumentasi MK nyatanya secara tegas disanggah oleh KY. Menurut KY, Perintah bagi Komisi Yudisial untuk melakukan pengawasan terhadap Mahkamah Konstitusi seperti yang tercantum di dalam Peraturan Pemerintah Pengganti Undang-Undang (Perppu) yang diterbitkan Presiden Susilo Bambang Yudhoyono, tidak melanggar Undang-Undang KY.

Dalam Perppu itu KY tidak ditugaskan untuk mengawasi hakim konstitusi, ataupun ikut dalam panel ahli untuk menyeleksi dan mengusulkan nama-nama calon Majelis Kehormatan Hakim Konstitusi (MKHK). Akan tetapi tugas KY lebih untuk membantu MKHK dan hanya dalam kapasitas panel ahli yang bersifat ad hoc.

\section{Kesimpulan}

Penyebab dari terkikisnya tujuan dari checks and balances di Indonesia sehingga terciptanya ketegangan antar lembaga negara adalah ketidakfahaman dari para aparatur negara dari tujuan check and balances yang menekankan pentingnya hubungan saling mengawasi dan mengendalikan antar berbagai lembaga negara agar pelaksanaan fungsi lembaga negara menjadi maksimal.

Namun, dewasa ini terlihat dalam pelaksanaan checks and balances yang dilakukan oleh lembaga negara yang satu kepada lembaga negara lain dianggap suatu ancaman untuk menjatuhkan eksistensi lembaga negara, dan menciptakan ego sektoral. Dapat terlihat saat Konstitusi mengamanahkan pada Komisi Yudisial untuk mengawasi perilaku hakim yang termasuk dalam kekuasaan kehakiman, namun Mahkamah Konstitusi menolak pengawasan tersebut. Begitupun Mahkamah Agung, terbukti sejak tahun 2011 sampai dengan sekarang terhambatnya perekrutan hakim MA, karena MA menolak KY ikut campur. Begitupula dengan kasus Undang-Undang tentang Pilkada melawan 
Peraturan Pengganti Undang-Undang tentang Pilkada. Selain itu ego sektoral antar lembaga negara terlihat pula pada kasus KPK dengan Polri.

Penyebab lain terkikisnya prinsip checks and balances antara lain: Pertama, masih banyaknya oknum dari aparatur negara yang dalam melaksanakan tugasnya tidak mengutamakan kepentingan masyarakat, dan malah mementingkan kepentingan partai politik yang dianggap paling berjasa. Kedua, tersendatnya komunikasi antar lembaga negara yang menyebabkan lembaga negara tersebut seringkali berselisih faham terkait dengan tugas dan fungsinya.

Oleh karena itu, cara untuk merejuvinasi wujud dari sistem checks and balances dalam ketatanegaraan di Indonesia yakni: pertama, membenahi seleksi rekrutmen calon pemimpin lembaga negara. Hal ini penting karena rekrutmen seleksi pimpinan lembaga negara selama ini sangat kental dengan aroma politik sehingga deal-deal politik tidak dapat dihindari. Kedua, mengupayakan agar aparatur negara melaksanakan tugasnya dengan berlandaskan asas-asas good governance, agar dapat menciptakan aparatur negara yang bersih, mengedepankan transparansi dan tanggung jawab, yang bebas korupsi, kolusi serta nepotisme. Ketiga, memperbaiki kembali paradigma bahwa checks and balances bukan merupakan suatu ancaman bagi setiap lembaga negara tetapi sebagai saran satu alat negara untuk menciptakan tata kelola negara yang baik.

\section{Pustaka Acuan}

\section{Buku-buku}

Hadjar, A. Fickar. ed. Pokok-pokok Pikiran dan Rancangan Undang-Undang Mahkamah Konstitusi, (Jakarta: KRHN dan Kemitraan, 2003).

Schmitt, Carl. Constitutional Theory, Translated and edited by Jeffrey Seitzer, Duke University Press, Durham and London, 2008.

Roy, Crince le. Kekuasaan ke-empat Pengenalan Ulang, diterjemahkan oleh Soehardjo, (Semarang: 1981).

Faisal, Menerobos Positivisme Hukum. Jakarta: Gramata Publishing, 2009.

Asshiddiqie, Jimly. Konstitusi dan Konstitusionalisme Indonesia, (Jakarta: Sekretariat Jenderal dan Kepaniteraan Mahkamah Konstitusi RI, 2006).

Maggalatung, A Salman; Yunus, Nur Rohim. Pokok-Pokok Teori Ilmu Negara, Cet1, Bandung: Fajar Media, 2013.

Maggalatung, A Salman. "Hubungan Antara Fakta Norma, Moral, Dan Doktrin Hukum Dalam Pertimbangan Putusan Hakim," dalam Jurnal Cita Hukum, Vol. 2, No. 2 (2014). 
Prins, WF; Adisapoetra, R. Kosim. Pengantar Ilmu Hukum Adiminstrasi Negara. Jakarta: Pradnya Paramita,1983.

Ridwan, HR. Hukum Administrasi Negara. (Jakarta: RajaGrafindo Persada, 2007).

Agusty, Rizza Zia; Siyo, Suryanto. "UUDNRI 1945 Lembaga Negara beserta Pimpinannya, peraturan perundang-undangan , dan kabinet trisakti." (Jakarta: Visi Media, 2014).

Sekretariat Jenderal MPRR.I., Panduan Dalam Memasyarakatkan UndangUndang DasarNegara Republik Indonesia Tahun 1945, Latar Belakang, Proses dan Hasil Perubahan Undang-Undang Dasar Negara Republik Indonesia Tahun 1945 (Jakarta: Sekretariat Jenderal MPR R.I. 2003).

\section{Kamus, Artikel, dan lain-lain.}

Black Law Dictionarry By Henry Campbel, (St. Paul: West Publishing Co., 1990).

Tempo, Selasa/30 September 2014, "SBY Siapkan Perpu Batalkan UU Pilkada", oleh Prihandoko.

Gatra News, Selasa/ 2 April 2013, "Korupsi dan Trias Politica", oleh Abdul Aziz.

Kompas, 1 Maret 2015 diunduh pada tanggal 27 Oktober 2015 dari situs http://nasional.kompas.com/read/2015/03/01/19475521/Jimly.Kasus.Budi. Gunawan.Berhenti.Abraham.Samad.dan.Bambang.Widjojanto.Juga.Har us.Dihentikan.

http://www.jimlyschool.com/read/analisis/333/checks-and-balances-dan-judicialreview-dalam-legislasi-di-indonesia/ pada tanggal 27 Oktober 2015.

http://www.jimlyschool.com/read/analisis/333/checks-and-balances-dan-judicialreview-dalam-legislasi-di-indonesia/ pada tanggal 27 Oktober 2015

Antara News, Rabu/ 19 Agustus 2015 diunduh pada tanggal 27 Oktober 2015 dari situs http://www.antaranews.com/berita/513237/ma-tolakrekomendasi-ky-soal-hakim-sarpin.

Hukum Online, Kamis/24 Agustus 2006, diunduh pada tanggal 27 Oktober 2015, pada situs http://www.hukumonline.com/berita/baca/hol15347/hakimmk-tak-mau-diawasi-ky. 
Memperkuat Hubungan Antar Lembaga Negara Dalam Bingkai Negara Hukum 